\title{
PENGARUH AKUNTABILITAS, TEMUAN AUDIT DAN TINDAK LANJUT HASIL AUDIT TERHADAP TINGKAT KORUPSI
}

\begin{abstract}
This study aims to detemine the effect of accountability, audit findings, and follow-up on audit results on the level of corruption in West Java Provinces periods of 20172018. The results showed that accountability, audit findings and follow-up to audit results had a simultaneous effect on the level of corruption. Partially the follow-up of audit results has a negative effect on the level of corruption, while accountability and audit findings do not have a significant effect on the level of corruption. The results of this study are expected to contribute in the form of empirical evidence that supports or rejects the results of previous research and provides input for policy makers who will be considered in preventing corruption in West Java Province and can describe each of the factors of Accountability, Audit Findings and Audit Follow-up and find the influence of each of these factors on the level of corruption in West Java.
\end{abstract}

ABSTRAK: Penelitian ini bertujuan untuk mengetahui pengaruh akuntabilitas, temuan audit, dan tindak lanjut hasil audit terhadap tingkat korupsi di Provinsi Jawa Barat periode 20172018. Populasi dalam penelitian ini adalah kota dan kabupaten Provinsi Jawa Barat periode 2017-2018. Hasil penelitian menunjukkan bahwa akuntabilitas, temuan audit dan tindak lanjut hasil audit berpengaruh simultan terhadap tingkat korupsi. Secara parsial tindak lanjut hasil audit berpengaruh negatif terhadap tingkat korupsi, sedangkan akuntabilitas dan temuan audit tidak memiliki pengaruh signifikan terhadap tingkat korupsi. Hasil penelitian ini diharapkan dapat memberikan kontribusi dalam bentuk bukti empiris yang mendukung atau menolak hasil penelitian sebelumnya dan memberikan masukan bagi pembuat kebijakan yang akan dipertimbangkan dalam mencegah terjadinya korupsi di Provinsi Jawa Barat dan dapat menggambarkan masing-masing faktor Akuntabilitas, Temuan Audit dan Tindak Lanjut Audit dan menemukan pengaruh masing-masing faktor tersebut terhadap Tingkat Korupsi di Jawa Barat.

\author{
Wiwin Aminah ${ }^{1}$ \\ Dosen Prodi Akuntansi FEB \\ Telkom University
}

Keyword:

Accountability, Audit

Findings, Audit Follow-Up

and Corruption Level

Kata Kunci: Akuntabilitas, Temuan Audit, Tindak Lanjut Audit dan Tingkat Korupsi 


\section{Pendahuluan}

Fenomena korupsi masih menjadi permasalahan di Indonesia dan semakin marak terjadi, dewasa ini Indonesia masih menjadi Negara yang paling bermasalah dalam korupsi di dunia. Berdasarkan data yang diperoleh dari Transparency International pada tahun 2018 Indonesia berada di skor 38 dan berada di peringkat 89 dari 180 negara yang disurvei. Indonesia Corruption Watch memaparkan pada tahun 2018, Provinsi Jawa Barat menempati posisi empat besar dalam kategori kasus korupsi tertinggi dari 34 Provinsi di Indonesia. Pada tahun 2018 Penegak hukum di wilayah Jawa Barat mampu menangani 27 kasus dugaan korupsi dengan menetapkan tersangka sebanyak 71 orang yang menghasilkan jumlah kerugian negara sebesar Rp51,400,000,000,000 dan nilai suap sebesar Rp10,300,000,000 (Indonesia Corruption Watch, 2018).

Penelitian terdahulu tentang tingkat korupsi di Indonesia telah dilakukan oleh Ahmad Ulil Albab Al Umar \& Anava Salsa Nur Savitri (2019), Verawaty, intan puspanita, dan Endah Sularti (2019), , Kiswanto, Ain Hajawijayah dan Nani Fitriani (2019),: Djoko Suhardjanto, Muchamad Syafruddin Rahajeng Putri Andini, Metha Wahyu Rahmatika (2018), Cyndi Putri Permata Sari Sitorus (2018), Dwi prihatni Amrih Rahayuningtyas dan Dyah Setyaningrum (2017), Rini dan Liska Damiati (2017). Berdasarkan penelitian terdahulu terdapat hasil yang tidak konsisten mengenai pengaruh Opini audit, temuan audit dan tindak lanjut hasil audit, menunjukkan bahwa temuan audit dan opini audit berpengaruh negatif, tindak lanjut hasil audit berpengaruh positif terhadap tingkat korupsi, Ahmad Ulil Albab Al Umar \& Anava Salsa Nur Savitri (2019), temuan audit, opini audit, tidak berpengaruh, tindak lanjut hasil audit berpengaruh negatif, Verawaty, intan puspanita, dan Endah Sularti (2019), temuan audit berpengaruh positif , Kiswanto, Ain Hajawijayah dan Nani Fitriani (2019), akuntabilitas tidak berpengaruh (Cyndi Putri Permata Sari Sitorus , 2018 obj). Penelitian ini berbeda dengan penelitia- penelitian sebelumnya adalah dari objek penelitian, penelitian terdahulu objeknya seluruh propinsi di Indonesia, dan provinsi jawa tengah.

Mengacu pada masalah penelitian dan penelitian terdahulu, motivasi penelitian ini diharapkan dapat memberi kontribusi berupa bukti empiris yang mendukung atau menolak hasil penelitian sebelumnya dan memberi masukan bagi pengambil kebijakan yang akan dijadikan pertimbangan dalam mencegah terjadinya korupsi serta menggambarkan masing-masing faktor dan menemukan pengaruh Akuntabilitas, temuan audit, dan tindak lanjut hasil audit terhadap tingkat korupsi di Provinsi Jawa Barat.

\section{Tinjauan Teori}

\section{Tingkat Korupsi}

Penelitian yang meneliti masalah tingkat korupsi di Indonesia maupun di provinsi lain telah dilakukan oleh beberapa peneliti. Penelitian Ahmad Ulil Albab Al Umar \& Anava Salsa Nur Savitri Ahmad, Analisa Hasil Audit Pemerintah Terhadap Tingkat Korupsi Pemerintahan Provinsi Jawa Tengah (2019), variabel-variabel dependen yang digunakan adalah Opini audit, temuan audit dan tindak lanjut hasil audit, hasil penelitian menunjukan bahwa temuan audit dan opini audit berpengaruh negatif, tindak lanjut hasil audit berpengaruh positif terhadap tingkat korupsi. Verawaty, intan puspanita, dan Endah Sularti, Pengaruh BPK Karakteristik Pemerintah dan Indeks Pembangunan Manusia terhadap Tingkat Korupsi pemerintah Daerah di Indonesia (2019) variabel-variabel dependen yang digunakan adalah Temuan audit, Tindak lanjut rekomendasi, opini audit, Hasil penelitian ini menunjukkan bahwa temuan audit, ukuran pemerintah, opini audit, belanja modal, dan indeks pembangunan manusia tidak berpengaruh terhadap tingkat korupsi. Sedangkan tindak lanjut hasil audit berpengaruh negatif, terhadap tingkat korupsi. Kiswanto, Ain Hajawijayah dan Nani Fitriani, The Effect Of Audit Results and Financial 
Performance on Corruption Level Moderated by Government Size 2012-2015 (2019) Variabel yang digunakan Temuan audit, Tindak lanjut rekomendasi, rasio kemandirian dan rasio aktivitas keuangan daerah Hasil penelitian ini menunjukkan bahwa tindak lanjut rekomendasi, berpengaruh negative, terhadap tingkat korupsi, temuan audit, dan rasio kemandirian berpengaruh positif terhadap tingkat korupsi. Rasio aktivitas keuangan daerah tidak berpengaruh terhadap tingkat korupsi di pemerintah provinsi di Indonesia. Sedangkan ukuran pemerintah secara signifikan memoderasi pengaruh kinerja keuangan pada tingkat korupsi. Cyndi Putri Permata Sari Sitorus, Pengaruh Transparasi Dan Akuntanbilitas Terhadap Tingkat Korupsi (Studi pada Pemerintah Daerah di Indonesia yang Disurvei oleh KPK di Tahun 2013) (2028), Variabel Indenepden : Transparansi dan Akuntabilitas, Hasil penelitian ini menunjukkan bahwa akuntabilitas dan transparansi tidak berpengaruh terhadap tingkat korupsi baik secara parsial maupun simultan.

Dari Penelitian terdahulu, Variabel yang konsisten berpengaruh terhadap tingkat korupsi adalah tindak lanjut audit.

\section{Akuntabilitas}

Dalam Peraturan Pemerintah Nomor 71 Tahun 2010 akuntabilitas merupakan suatu hal dengan mempertanggungjawabkan pengelolaan sumber daya serta pelaksanaan kebijakan yang dipercayakan kepada entitas pelaporan dalam mencapai tujuan yang telah ditetapkan. Menurut UU No. 15 Tahun 2006 tentang Badan Pemeriksa Keuangan, seiring dengan hasil pemeriksaan keuangan oleh BPKRI atas LKPD akuntabilitas dapat ditentukan dalam tiga kategori, yaitu:

\section{Opini Audit}

Opini merupakan pernyataan profesional pemeriksa mengenai kewajaran informasi keuangan yang disajikan dalam laporan keuangan yang didasarkan pada kriteria Opini Audit. Opini audit Badan Pemeriksa Keuangan RI terdiri dari 5 opini, yaitu wajar tanpa pengecualian (WTP/Unqualified Opinion), wajar tanpa pengecualian dengan paragraph penjelas (WTP DPP), wajar dengan pengecualian (WDP/Qualified Opinion), Tidak Wajar (TW/Adverse Opinion), dan tidak memberikan pendapat (TMP/Disclaimer Opinion).

\section{Sistem Pengendalian Internal (SPI)}

Pemeriksaan atas sistem pengendalian internal dilakukan untuk memaparkan tingkat kelemahan pengendalian internal yang terdapat pada suatu entitas.

Kepatuhan terhadap Ketentuan
Perundang-undangan
Dalam penelitian ini, proxy yang digunakan dalam mengukur akuntanbilitas yaitu pendapat/opini audit atas kewajaran informasi keuangan yang disajikan dalam laporan keuangan dengan menggunakan skala 1-4 yaitu : Opini Audit Opini Audit Nilai Wajar Tanpa Pengecualian nilai 4; Wajar dengan Pengecualian nilai 3 ; Tidak Wajar nilai 2; Tidak Memberikan Pendapat nilai 1 \{Sumber: Khairudin \& Erlanda (2016). Hasil Penelitian Rahayuningtyas \& Setyaningrum (2017) menyatakan bahwa Akuntabilitas kinerja berpengaruh negatif terhadap persepsi korupsi. Hal ini sejalan dengan penelitian yang dilakukan oleh Khairiyyah (2019) dimana hasil penelitiannya menunjukkan bahwa akuntanbilitas berpengaruh negatif dan signifikan terhadap korupsi.

H1 : Akuntanbilitas berpengaruh negatif terhadap tingkat korupsi

\section{Temuan Audit}

Huefner, Ronald J (2011) menyatakan bahwa cara yang utama untuk mencegah terjadinya kecurangan (fraud) yaitu dengan kuatnya sistem pengendalian internal yang ada. Sehingga semakin banyak temuan kelemahan pengendalian internal dan kepatuhan terhadap perundang-undangan akan meningkatkan kemungkinan terjadinya korupsi dan sebaliknya jika temuan tersebut sedikit maka kemungkinan terjadinya korupsi akan lebih 
kecil. Kiswanto et al. (2019) yang menyatakan bahwa ada efek positif dari Badan Pemeriksa Indonesia Temuan Audit pada tingkat korupsi. Masyitoh et al (2015) dan penelitian (Azhar \& Setyaningrum, 2015) yang menyatakan bahwa temuan audit atas ketidak patuhan pada perundang-undangan berpengaruh positif terhadap persepsi korupsi.

H2 : Temuan Audit berpengaruh positif terhadap tingkat korupsi

\section{Tindak Lanjut Hasil Audit}

Menurut Liu \& Lin (2012) menyatakan bahwa perbaikan setelah adanya proses audit (audit rectification) merupakan sebuah langkah awal yang lebih penting dari deteksi atas temuan audit itu sendiri karena upaya untuk melakukan perbaikan setelah audit dapat meningktnya efektivitas proses audit serta mencegah atau mengantisipasi terjadinya temuan yang sama di masa yang akan datang. Jika perbaikan setelah audit tidak dilaksanakan maka tindakan korupsi dan pelanggaranpelanggaran akan selalu terjadi. Hal ini sejalan dengan penelitian yang dilakukan oleh Rini \& Damiati dan Verawaty et al yang menunjukkan bahwa tindak lanjut rekomendasi berpengaruh negatif terhadap tingkat korupsi. Dapat disimpulkan bahwa semakin banyak rekomendasi-rekomendasi auditor yang ditindaklanjuti oleh pemerintah akan menunjukkan tingkat korupsi yang lebih rendah.

$\mathrm{H} 2$ : Temuan Audit berpengaruh negatif terhadap tingkat korupsi

\section{Metode Penelitian}

\section{Jenis dan sumber Data}

Populasi dalam penelitian ini adalah seluruh pemerintah kota dan pemerintah kabupaten di Provinsi Jawa Barat pada tahun 2017-2018, yaitu berjumlah 27 kota dan kabupaten
Teknik pengambilan sampel yang digunakan dalam penelitian ini adalah purposive sampling (sampel kriteria). Kriteria dalam pengambilan sampel adalah

Jumlah kota dan kabupaten di Jawa Barat tahun 2017-2018, adalah (27) Kota atau kabupaten yang memiliki data lengkap seluruh variabel tahun 2017-2018, yang tidak lengkap terdapat (3), maka Kota (8 kota) dan Kabupaten (16 kabupaten) yang memperoleh opini audit, temuan dan tindak lanjut hasil audit dari Badan Pemeriksa Keuangan (BPK) RI. Atas kriteria tersebut diperoleh total sampel yang digunakan dalam penelitian ini sebanyak 48 sampel yang terdiri dari 16 pemerintah kabupaten dan 8 pemerintah kota tahun 20172018, $(16+8)=24 \times 2$ th $\square 48$ sampel

\section{Metode Pengumpulan data}

Penelitian ini menggunakan data sekunder yang mengacu pada informasi yang telah ada. Sumber data yang digunakan adalah Ikhtisar Hasil Pemeriksaan Semester II tahun 2018 BPK RI yang berupa opini audit, temuan audit dan tindak lanjut hasil audit. Selain itu peneliti menggunakan data dari Indonesia Corruption Watch (ICW). Variabel

Definisi Operasional dan Pengukuran

Akuntabilitas

Akuntabilitas keuangan adalah bentuk pertanggungjawaban menyangkut masalah keuangan, pengungkapan, dan kepatuhan terhadap peraturan hukum (Mardiasmo, 2009) variabel ini diukur dengan opini audit $\mathrm{WTP}=4$ $\mathrm{WDP}=3 \mathrm{TW}=2 \mathrm{TMP}=1$ dengan skala interval.

\section{Temuan Audit}

Temuan audit dapat dikatakan sebagai hasil pemeriksaan Badan pemeriksa keuangan (BPK) yang menunjukkan temuan-temuan, baik temuan atas pengendalian internal maupun temuan atas ketidak patuhan terhadap perundang-undangan, diukur dengan Jumlah temuan pemeriksaan BPK RI yang disesuaikan dengan jumlah populasi (temuan perkapita) dengan skala nominal

Tindak Lanjut Hasil Audit 
Tindak lanjut hasil audit merupakan saran dari pemeriksa berdasarkan hasil dari pemeriksaannya yang ditujukan kepada orang/badan yang berwenang untuk melakukan tindakan perbaikan, diukur denga total nilai yang diserahkan ke kas negara oleh BPK (rupiah perkapita) dengan skala nominal.

Tingkat Korupsi

Merupakan tindakan melawan hukum yang dilakukan oleh setiap orang atau korporasi untuk memperkaya diri sendiri, orang lain atau suatu korporasi yang, menyalahkan kewenangan maupun jabatan atau kedudukan yang dapat merugikan keuangan negara atau perekonomian Negara, jumlah kasus korupsi kabupaten dan kota di Provinsi Jawa Barat tahun 2017-2018 diukur dengan jumlah kasus korupsi kabupaten dan kota di Provinsi Jawa Barat tahun 2017-2018, dengan skala nominal.

Teknik dan Pengujian Hipotesis

Teknik analisis data yang digunakan adalah analisis deskriptif dan analisis regresi. Kemudian analisis regresi betganda dilakukan untuk menguji hipotesis dalam penelitian ini, peneliti menggunakan analisis regresi berganda, dengan tahapan sebagai berikut: a. Uji Asumsi Klasik, b. Uji Normalitas, c. Uji Multikolonieritas, d. Uji Heterokedastisitas, e. Uji Hipotesis,

Persamaan regresi linear berganda sebagai berikut :

$\beta 1 \mathrm{X} 1+\beta 2 \mathrm{X} 2+\beta 3 \mathrm{X} 3+\mathrm{e}$

Keterangan:

CORRUPT : Jumlah kasus tindak pidana korupsi

a : Konstanta

ACC : Akuntabilitas

AUIRR : Jumlah Temuan Audit BPK Keterangan: pidana korupsi

\section{Hasil Penelitian}

Analisis Deskriptif

Tabel 4. 1 Hasil Uji Statistik Deskriptif

\begin{tabular}{|l|l|l|l|l|l|}
\hline $\begin{array}{l}\text { Variabe } \\
\text { l }\end{array}$ & $\mathbf{N}$ & Min & Max & Mean & $\begin{array}{l}\text { Std. } \\
\text { Deviasi }\end{array}$ \\
\hline $\begin{array}{l}\text { CORRU } \\
\text { PT }\end{array}$ & 4 & 0 & 5 & $\begin{array}{l}1.2083 \\
33\end{array}$ & $\begin{array}{l}1.23698 \\
9\end{array}$ \\
\hline ACC & 4 & 3 & 4 & $\begin{array}{l}3.8958 \\
33\end{array}$ & 0.30870 \\
& 8 & & & 9 \\
\hline AUIRR & 4 & 0.0000 & 0.0000 & 0.0000 & 0.00001 \\
& 8 & 03 & 82 & 17 & 79 \\
\hline AUREC & 4 & 0.0000 & 0.0002 & 0.0000 & 0.00004 \\
& 8 & 06 & 30 & 49 & 8 \\
\hline
\end{tabular}

(Sumber: Data yang telah diolah penulis, 2020)

Berdasarkan hasil uji statsitik deskriptif diperoleh sebanyak 48 data observasi yang berasal dari jumlah sampel pemerintah kota dan kabupaten di Jawa Barat. Tabel 4.1 Pada variabel pertama yaitu tingkat korupsi yang diukur dengan jumlah kasus korupsi di kota dan kabupaten di Jawa Barat periode 2017-2018 memiliki nilai minimum sebesar 0 yang dimiliki oleh beberapa kota dan kabupaten yang tidak memiliki kasus korupsi. Nilai maksimum kasus korupsi sebesar 5 yang dimiliki oleh kabupaten Subang pada tahun 2018.

\section{Akuntabilitas}

Akuntabilitas memiliki nilai minimum 3 dengan nilai maksimum 4 karena menggunakan pengukuran skala interval 1 sampai 4, diketahui secara rata-rata opini yang didapatkan oleh pemerintah kota dan kabupaten di Jawa Barat adalah WTP (wajar tanpa pengecualian) yaitu dengan nilai 4 , namun jumlah pemerintah kota dan kabupaten yang mendapatkan opini WTP dan selain WTP jumlahnya tidak berbeda jauh terlihat dari nilai rata-rata sebesar 3.9. Standar deviasi untuk variabel akuntabilitas (ACC) adalah 0.3. Hasil audit yang dikemukakan oleh BPK dalam laporan Ikhtisar Hasil Pemeriksaan per semester setiap tahunnya, menunjukkan peningkatan kualitas audit di kota dan kabupaten di Jawa Barat yang dapat dilihat dari semakin banyaknya yang mendapatkan opini wajar tanpa pengecualian dan semakin menurunnya Kota dan Kabupaten yang menjadi sampel mendapat opini tidak wajar 
Journal Accounting and Finance

Edisi Vol. 4 No. 2 September 2020

\section{Temuan Audit}

Jumlah temuan audit oleh BPK pada kota dan kabupaten yang menjadi sampel sebanyak 0.000017 kasus perkapita, atau 1,7 kasus untuk setiap 100.000 penduduk. Jumlah rata-rata temuan audit ini terbilang cukup rendah yang menandakan bahwa pemerintah kota dan kabupaten yang menjadi sampel dalam penelitian ini memiliki kinerja yang cukup baik. Temuan tertinggi sebesar 0.000082 kasus perkapita yang dimiliki oleh kota Banjar pada tahun 2018 sedangkan temuan audit terendah sebesar 0.000003 kasus perkapita yang dimiliki oleh kabupaten Bekasi pada tahun 2018. Standar deviasi untuk variabel temuan audit (AUIRR) adalah 0.00001795 temuan perkapita. Nilai standar deviasi tidak jauh berbeda dengan nilai rata-rata ini menunjukkan varian yang tinggi, artinya kelompok data tersebut sangat bervariasi atau relatif heterogen, menyebar dan jauh dari rata-rata.

\section{Tindak Lanjut Audit}

Rata-rata nilai penyetoran atau penyerahan asset ke kas negara/daerah/perusahaan sebagai bentuk dari tindak lanjut rekomendasi yang diberikan oleh BPK atas temuan audit yaitu sebesar Rp49 perkapita. Tindak lanjut hasil audit yang tertinggi yaitu Kota Banjar dengan nilai Rp230 perkapita. Sedangkan tindak lanjut hasil audit yang terendah yaitu Kabupaten Cirebon tahun 2018 sebesar Rp6 perkapita. Standar deviasi untuk variabel tindak lanjut hasil audit adalah Rp48,7. Tingginya tindak lanjut hasil audit yang diukur dari nilai penyetoran asset ke kas Negara sebagai bentuk dari tindak lanjut rekomendasi yang telah diberikan oleh BPK dalam IHPS, oleh pemerintah kota Banjar diduga disebabkan oleh akan adanya kesadaran untuk mengembalikan ke kas Negara hasil dari temuan-temuan audit dalam penyelewengan dan kepatuhan terhadap perundang-undangan. Sebaliknya kedua kemungkinan tersebut belum ada di kabupaten Cirebon sehingga tindak lanjut rekomendasi atas hasil auditnya paling rendah diantara kota dan kabupaten yang lain

\section{Universitas Telkom}

\section{Tingkat korupsi}

Tingkat korupsi yang diukur menggunakan jumlah seluruh kasus korupsi di kota dan kabupaten di Jawa Barat didapatkan dari Indonesia Corruption Watch. Hasil analisis deksriptif tingkat korupsi sebagai berikut.

Pada tabel 4.1 dapat dilihat bahwa hasil pengujian statistik deskriptif dari korupsi pada tahun 2017 pada kota dan kabupaten di Jawa Barat memiliki nilai minimum sebesar 0 (nol) kasus yang terdapat di beberapa kota dan kabupaten. nilai maximum korupsi sebesar 4 kasus yang dimiliki oleh kabupaten Purwakarta dan kabupaten Cianjur. Selanjutnya nilai mean korupsi sebesar 1.6 dan nilai standar deviasi pada variabel korupsi ini sebesar 1.3. Hal ini mencerminkan bahwa kota dan kabupaten yang menjadi sampel memiliki nilai mean yang positif sebesar 1.6 dan lebih atau diatas nol dimana dapat dikatakan kesempatan tindak pidana korupsi pun dapat terjadi. Nilai standar deviasi lebih rendah dari rata-rata menunjukkan varian yang rendah, artinya kelompok data tersebut tidak bervariasi atau relatif homogen, berkelompok dan mendekati rata-rata. Pada tahun 2018, jumlah kasus tindak pidana korupsi paling tinggi yaitu sebnayak 5 kasus, ini dimiliki oleh kabupaten Subang, nilai ini menjadi nilai tertinggi selama tahun penelitian. Selanjutnya jumlah kasus tindak pidana korupsi paling rendah yaitu sebanyak 0 yang dimiliki oleh beberapa kota dan kabupaten yang menjadi sampel. Secara ratarata jumlah tindak pidana korupsi adalah sebanyak 0kj.83 kasus dan nilai standar deviasi sebesar 1.09. Hal ini mencerminkan bahwa kota dan kabupaten yang menjadi sampel memiliki nilai yang positif terhadap tindak pidana korupsi. Nilai standar deviasi yang lebih tinggi dari nilai ratarata menunjukkan penyebaran data yang bagus serta data bervariasi atau jauh dari rata-rata (heterogen).

\section{Uji Asumsi Klasik}

Tujuan Uji asumsi klasik, adalah untuk mengetahui bahwa asumsi-asumsi yang mendasari model regresi dalam penelitian apakah terjadinya normalitas atau apakah terjadi atau tidaknya gejala multikolonierisitas dan gejala heterodeksitas. 
Sehingga dapat menghasilkan penduga yang tidak bias. Berikut adalah hasil uji asumsi klasik

\section{Uji Normalitas}

Tujuan uji normalitas adalah untuk melihat apakah nilai residual berdistribusi normal atau tidak. Jika nilai residual berdistribusi normal maka regresi yang digunakan dinilai baik. Jika nilai signifikansi lebih besar dari 5\% maka dinyatakan residual menyebar normal, dan jika nilai signifikansi lebih kecil dari 5\% maka dinyatakan residual menyebar tidak normal. Berikut ini hasil uji normalitas ditunjukkan tabel 4.2 dibawah ini:

\section{Tabel 4.2 Uji Normalitas}

\begin{tabular}{|lc|}
\hline \multicolumn{2}{|l|}{ Series: Residuals } \\
Sample 1 48 \\
Observations 48 \\
Mean & $4.36 \mathrm{e}-13$ \\
Median & 0.005883 \\
Maximum & 0.298783 \\
Minimum & -0.338080 \\
Std. Dev. & 0.175320 \\
Skewness & 0.316712 \\
Kurtosis & 2.378065 \\
& \\
Jarque-Bera & 1.576061 \\
Probability & 0.454740 \\
\hline
\end{tabular}

(Sumber: Hasil Pengolahan Data E-Views 10, 2020)

\section{Uji Multikolonierisitas}

Uji multikolonierisitas bertujuan untuk menguji apakah model regresi ditemukan adanya korelasi antar variabel bebas (independen). Besaran korelasi antarvariabel harus kurang dari 0.90 agar penelitian terbebas dari multikolenierisitas. Hasil uji multikolenierisitas dapat dilihat pada tabel 4.3

Tabel 4.3 Hasil Uji Multikolenierisitas

\begin{tabular}{ccrr}
\hline & \multicolumn{1}{c}{ X1 } & \multicolumn{1}{c}{ X2 } & \multicolumn{1}{c}{ X3 } \\
\hline \hline X1 & 1.000000 & -0.071103 & 0.140899 \\
X2 & -0.071103 & 1.000000 & -0.504637 \\
X3 & 0.140899 & -0.504637 & 1.000000
\end{tabular}

(Sumber: Hasil Pengolahan Data E-Views 10, 2020)

Pada tabel 4.3 menunjukkan bahwa hasil analisis akuntabilitas (X1), 1,000000 temuan audit (X2), 0.071103, dan tindak lanjut hasil audit (X3) 0.140899. Dari hasil tersebut, maka dapat disimpulkan bahwa tidak terjadi multikoleniaritas, karena koefisien antar variabel lebih kecil dari 0.90 .

\section{Uji Heterokedastisitas}

Uji heterokedasitisitas merupakan uji yang terjadi apabila terdapat varians yang berbeda untuk variabel independen yang berbeda. Agar terbebas dari gejala heterokedastisitas, nilai probabilitas dalam uji heterokedastisitas setiap variabel independen harus lebih besar dari 0.05. Hasil uji heterokedastisitas dapat dilihat pada tabel 4.4 berikut :

\section{Tabel 4.4 Hasil Uji Heterokedastisitas}

\begin{tabular}{crrrr}
\hline \hline Variable & Coefficient & Std. Error & t-Statistic & Prob. \\
\hline \hline X1 & 0.061051 & 1.033360 & 0.059080 & 0.9532 \\
X2 & -135.2320 & 95.64863 & -1.413842 & 0.1644 \\
X3 & 21.36464 & 545.6138 & 0.039157 & 0.9689 \\
C & 113.9775 & 599.2100 & 0.190213 & 0.8500 \\
\hline
\end{tabular}

(Sumber: Hasil Pengolahan Data E-Views 10, 2020)

Berdasarkan tabel 4.4 menunjukkan hasil uji heterokedastisitas bahwa probabilitas dari masingmasing variabel independen yaitu lebih besar dari 0.05 . Sehingga dapat disimpulkan penelitian ini bebas dari gejala heterokedastisitas pada setiap variabel independen.

\section{Analisis Regresi Linier Berganda}

Penelitian ini menggunakan teknik analasis regresi linier berganda dengan menggunakan E-views 10. Analisis regresi linear berganda dilakukan untuk menguji hipotesis terkait pengaruh variabel independen akuntabilitas, temuan audit dan tindak lanjut audit terhadap variabel dependen tingkat korupsi, secara simultan maupun parsial. Terdapat tiga hipotesis yang diuji dengan menggunakan teknik regresi berganda yaitu uji t, uji f dan uji koefisien determinasi (uji $\mathrm{r}^{2}$ ). 
Uji Koefisien Determinasi $\left(\mathrm{R}^{2}\right)$

Uji koefisien determinasi (adjusted $\mathrm{R}^{2}$ ) dilakukan untuk melihat tingkat ketepatan regresi linear berganda atau sejauh mana variabel-variabel independen dapat menjelaskan variabel dependen. Nilai koefisien determminasi berkisar antara 0 (tidak ada hubungan sama sekali) sampai 1 (hubungan sempurna). Hasil uji koefisien determinasi ditunjukkan dalam gambar 4.4 dibawah ini:

\section{Tabel 4.5 Hasil Uji Determinasi $\left(R^{2}\right)$}

\begin{tabular}{lrlr}
\hline \hline R-squared & 0.206125 & Mean dependent var & 0.748802 \\
Adjusted R-squared & 0.151997 & S.D. dependent var & 0.196769 \\
S.E. of regression & 0.181199 & Akaike info criterion & -0.498789 \\
Sum squared resid & 1.444652 & Schwarz criterion & -0.342856 \\
Log likelihood & 15.97094 & Hannan-Quinn criter. & -0.439861 \\
F-statistic & 3.808113 & Durbin-Watson stat & 2.397308 \\
Prob(F-statistic) & 0.016416 & & \\
\hline
\end{tabular}

(Sumber: Hasil Pengolahan Data E-Views 10, 2020)

Berdasarkan tabel 4.5 dapat dilihat bahwa nilai adjusted $R$-square sebesar 0,151997 atau sebesar 15,19\%, kemudian dapat disimpulkan bahwa variabel independen yaitu akuntabilitas, temuan audit dan tindak lanjut hasil audit mampu menggambarkan variansi dari tingkat korupsi sebesar $15,19 \%$ dan sisanya $84,81 \%$ digambarkan oleh faktor-faktor lainnya diluar variabel independen dalam penelitian ini.

\section{Uji Simultan ( Uji F)}

Pengujian ini menggunakan tingkat signifikansi sebesar 0.05. Hasil uji simultan ditunjukkan oleh tabel 4.6 dibawah ini:

Tabel 4.6 Hasil Uji Simultan ( Uji F)

\begin{tabular}{lrlr}
\hline \hline R-squared & 0.206125 & Mean dependent var & 0.748802 \\
Adjusted R-squared & 0.151997 & S.D. dependent var & 0.196769 \\
S.E. of regression & 0.181199 & Akaike info criterion & -0.498789 \\
Sum squared resid & 1.444652 & Schwarz criterion & -0.342856 \\
Log likelihood & 15.97094 & Hannan-Quinn criter. & -0.439861 \\
F-statistic & 3.808113 & Durbin-Watson stat & 2.397308 \\
Prob(F-statistic) & 0.016416 & & \\
\hline \hline
\end{tabular}

(Sumber: Hasil Pengolahan Data E-Views 10, 2020)

Berdasarkan tabel 4.6 dapat dilihat bahwa nilai profitabilitas (F-Statistic) memiliki nilai sebesar 0,016416 atau lebih kecil dari nilai signifikansi
0,05. Maka dapat disimpulkan bahwa variabel independen yaitu akuntabilitas, temuan audit dan tindak lanjut hasil audit secara simultan berpengaruh signifikan terhadap variabel dependen yaitu tingkat korupsi.

Uji Parsial (Uji t)

Uji pairsal bertujuan untuk menguji pengaruh variabel independen secara individual atau parsial terhadap variabel dependen. Dasar pengambilan keputusan dilakukan dengan cara membandingkan nilai signifikansi yang diperoleh dari hasil pengolahan E-views 10 dengan $\alpha=0,05$. Jika signifikansi lebih kecil dari 0,05 berarti pengaruh variabel independen terhadap variabel dependennya signifikan (H0 ditolak, Ha diterima) dan Hasil uji parsail ditunjukkan dalam tabel 4.7 dibawah ini:

Tabel 4.7 Hasil Uji Parsial (Uji t)

\begin{tabular}{|crrrr}
\hline \hline Variable & Coefficient & Std. Error & t-Statistic & Prob. \\
\hline \hline X1 & 2.330366 & 1.637861 & 1.422811 & 0.1618 \\
X2 & 84.52010 & 151.6018 & 0.557514 & 0.5800 \\
X3 & -2142.632 & 864.7903 & -2.477632 & 0.0171 \\
C & 2057.771 & 949.7395 & 2.166669 & 0.0357 \\
\hline \hline
\end{tabular}

(Sumber: Hasil Pengolahan Data E-Views 10, 2020)

Berdasarkan hasil analisis regresi pada tabel 4.7 diatas, dapat dibuat persamaan regresi untuk model penelitian sebagai berikut:

\section{Tingkat korupsi $=2057,7+2,330 \mathrm{ACC}+$ 84,520AUIRR - 2142,6AUREC + e}

Berdasarkan tabel 4.7 hasil pengujian parsial menggunakan regresi berganda dapat diketahui bahwa variabel akuntabilitas memiliki nilai koefisien regresi sebesar 2.330366 dengan tingkat probabilitas 0.1618 lebih besar dari $\alpha=0,05$. Dengan demikian menerima $\mathrm{H}_{0}$, dan $\mathrm{H}_{\mathrm{a} 1}$ ditolak akuntabilitas tidak memiliki pengaruh terhadap tingkat korupsi di kota dan kabupaten di Jawa Barat periode 2017-2018 
Data kota dan kabupaten yang memiliki angka akuntabilitas di atas rata-rata cenderung memiliki tingkat korupsi yang rendah yakni sebanyak 28 data. Begitu juga dengan kota dan kabupaten yang memiliki angka akuntabilitas dibawah rata-rata memiliki angka tingkat korupsi yang rendah sebanyak 5 data. Secara deskriptif hasil tersebut menunjukkan bahwa akuntabilitas yang tinggi maupun rendah memiliki tingkat korupsi dibawah rata-rata. Hasil ini yang menjelaskan secara deskriptif variabel akuntabilitas tidak berpengaruh pada tingkat korupsi. Hasil penelitian ini mendukung hasil penelitian sebelumnya yang dilakukan oleh Sitorus \& Rahayu (2018) yang membuktikan bahwa akuntabilitas tidak berpengaruh terhadap persepsi korupsi di pemerintah daerah.

\section{Pengaruh Temuan Audit terhadap Tingkat Korupsi}

Berdasarkan tabel 4.7 menunjukkan bahwa variabel temuan audit memiliki nilai koefisien regresi sebesar 84.52010 dengan tingkat probabilitas 0.5800 lebih besar dari $\alpha=0,05$, artinya tidak memiliki pengaruh terhadap tingkat korupsi. Dengan demikian $\mathrm{H}_{0}$ diterima, dan $\mathrm{H}_{\mathrm{a} 2}$ ditolak, variabel temuan audit tidak memiliki pengaruh terhadap tingkat korupsi di kota dan kabupaten di Jawa Barat periode 2017-2018. Data kota dan kabupaten yang memiliki audit dibawah rata-rata cenderung melakukan korupsi sebanyak 15 data. Sedangkan kota dan kabupaten yang memiliki temuan audit dibawah rata-rata memiliki angka tingkat korupsi dibawah rata-rata dengan 26 data. Sesuai dengan data yang menjelaskan bawah baik kota maupun kabupaten yang memiliki tingkat korupsi di atas maupun di bawah rata-rata mayoritas cenderung memiliki temuan audit dibawah rata-rata, maka variabel akuntabilitas tidak berpengaruh terhadap tingkat korupsi. Hasil penelitian ini mendukung hasil penelitian sebelumnya yang dilakukan oleh Masyitoh et al (2015) dan Verawaty et al (2019) yang membuktikan bahwa temuan audit tidak berpengaruh terhadap persepsi korupsi di pemerintah daerah.
Pengaruh Tindak Lanjut Hasil Audit terhadap Tingkat Korupsi

Hasil uji hipotesis pada tabel 4.6 menunjukkan bahwa variabel tindak lanjut hasil audit menunjukkan bahwa tindak lanjut rekomendasi berpengaruh terhadap tingkat korupsi dengan nilai koefisien regresi sebesar -2142.771 dengan tingkat probabilitas 0.0171 dan nilai tersebut lebih kecil dari $\alpha=0,05$. Maka dari itu, $\mathrm{H}_{0}$ ditolak dan $\mathrm{H}_{\mathrm{a} 3}$ diterima, artinya tindak lanjut audit berpengaruh terhadap tingkat korupsi, hal ini sejalan dengan penelitian Umar (2012) dalam Rini \& Damiati (2017) yang menyatakan bahwa dengan adanya masukan dari auditor, pihak pengambil keputusan dapat menghentikan dan mencegah terulangnya kembali kesalahan-kesalahan, penyimpangan yang dilakukan dan penyelewangan serta pemborosan dalam anggaran. Dengan demikian, pemerintah daerah yang melakukan apa yang telah direkomendasi oleh auditor BPK, pemerintah daerah telah berupaya dalam memperbaiki kesalahan, pengendalian internal dan kinerjanya sehingga menurunnya tingkat korupsi

\section{Kesimpulan}

Berdasarkan hasil penelitian dan pembahasan, maka dapat disimpulkan beberapa hal sebagai berikut:

Berdasarkan pengujian hipotesis secara simultan menunjukkan bahwa variabel independen yaitu akuntabilitas, temuan audit dan tindak lanjut hasil audit secara bersama-sama berpengaruh terhadap tingkat korupsi pada pemerintahan Provinsi Jawa Barat tahun 2017-2018

Berdasarkan pengujian secara parsial menunjukkan bahwa:

Akuntabilitas tidak berpengaruh terhadap tingkat korupsi pemerintahan kota dan kabupaten Provinsi Jawa Barat tahun 2017-2018.

Temuan audit tidak berpengaruh terhadap tingkat korupsi pemerintahan kota dan kabupaten Provinsi Jawa Barat tahun 2017-2018.

Tindak lanjut hasil audit berpengaruh negatif terhadap tingkat korupsi pemerintahan kota dan kabupaten Provinsi Jawa Barat tahun 2017-2018. 
Saran

Hasil penelitian ini menunjukkan adanya pengaruh yang signifikan antara tindak lanjut hasil audit dengan tingkat korupsi. Semakin banyak tindak lanjut atas rekomendasi auditor yang dilakukan pemerintah daerah dapat memperkecil kemungkinan terjadinya korupsi sehingga baik pemerintah daerah maupun auditor diharapkan dapat meningkatkan pengawasan atas pelaksanaan tindak lanjut hasil audit agar korupsi bisa diminimalkan

\section{Daftar Pustaka}

Ghozali, I. (2017). Analisis Multivariat dan Ekonometrika. Semarang: Undip.

Ghozali, I. (2018). Aplikasi Analisis Multivariate dengan Program IBM SPSS 25. Semarang: Badan Penerbit Universitas Diponegoro.

Mardiasmo. (2009). Akuntansi Sektor Publik. Yogyakarta: ANDI.

Sekaran, \& Roger, B. (2011). Metode Penelitian untuk Bisnis. Jakarta: Salemba Empat.

Sekaran, U. (2014). Research Methods for Business: Metode Penelitian untuk Bisnis (Edisi 4). Jakarta: Salemba Empat.

Sekaran, U., \& Roger, B. (2017). Metode Penelitian Untuk Bisnis. Jakarta: Salemba Empat.

Sugiyono, P. D. (2018). Metode Penelitian Kuantitatif. Bandung: ALFABETA.

Tugiman, H. (2006). Standar Profesional Audit Internal. Yogyakarta: Kanisius.

JURNAL :

Al Umar, A. A., \& Savitri, A. N. (2019). Analisa Hasil Audit Pemerintah Terhadap Tingkat Korupsi Pemerintahan Provinsi Jawa Tengah. Accounting Global Journal, 103-117.

Anonim. (2019). 3 Strategi Pemberantasan Korupsi. Diambil kembali dari Pusat Edukasi Antikorupsi: https://aclc.kpk.go.id/

Arsana, I. P. (2016). Manajemen Pengadaan Barang dan Jasa Pemerintah. Yogyakarta: Deepublish.
Dinillah, M. (2018, December 27). 5 Kepala Daerah di Jabar yang Ditangkap KPK Sepanjang 2018. Diambil kembali dari https://news.detik.com/

Ghaniy, N., \& Hastiadi, F. F. (2017). Political, Social and Economic Determinants Of Corruption. International Journal of Economics and Financial Issues.

Gunarwanto. (2019, july 10). Opini WTP versus Korupsi. [Online]. Tersedia: https://news.detik.com/

Huefner, Ronald J (2011) Fraud Risk in local gouvernment : Am Analysis of Audit Findings Journal Forensik \& Investigative Accounting (3) . 111-125

Khairiyyah, S. N. (2019). Transparansi, Akuntabilitas, dan Temuan Audit dalam Meminimalisasi Tingkat Korupsi (Studi pada Kementerian/Lembaga dan Pemerintah Daerah yang Disurvei KPK Tahun 2017).

Khairudin, \& Erlanda, R. (2016). Pengaruh Transparansi Dan Akuntabilitas Laporan Keuangan Pemerintah Daerah (LKPD) Terhadap Tingkat Korupsi Pemerintah Daerah (Studi Pada Pemerintah Kota Se-Sumatera). Jurnal Akuntansi \& Keunagan, 137-153.

Kiswanto, Hajawiyah, A., \& Fitriani, N. (2019). The Effect of Audit Results and Financial Performance on Corruption Level Moderated by Government Size. International Journal of Economics and Business Administration, 250259.

Komisi Pemberantasan Korupsi. (2019). TPK Berdasarkan Instansi. [Online]. Tersedia : https://www.kpk.go.id/id/statistik/penindakan/t pk-berdasarkan-instansi [30 September 2019].

Liu J \& LiB (2012) Gouvernment Auditing and Corruption control : evidence from China's Provincial Panel Data, China jurnal of Accounting Research5, 163-186

Masyitoh, R. D., Wardhani, R., \& Setyaningrum, D. (2015). Pengaruh Opini Audit, Temuan Audit dan Tindak Lanjut Hasil Audit terhadap Persepsi Korupsi pada Pemerintah Daerah Kabupaten/Kota Tingkat II Tahun 2008-2010. Simposium Nasional Akuntansi 18 Medan. 
Journal Accounting and Finance

Edisi Vol. 4 No. 2 September 2020

Peraturan Pemerintah Republik Indonesia Nomor 71 Tahun 2010. Tentang Standar Akuntansi Pemerintahan. Indonesia.

Rahayuningtyas, D. P., \& Setyaningrum, D. (2017). Pengaruh Tata Kelola dan EGovernment Terhadap Korupsi. Jurnal Ekonomi dan Keuangan, 431-450.

Rini, R., \& Damiati, L. (2017). Analisis Hasil Audit Pemerintahan dan Tingkat Korupsi Pemerintahan Provinsi di Indonesia. Jurnal Dinamika Akuntansi dan Bisnis, 73-90.

Rosyadi, C. F., \& Budding, T. (2017). The Effectiveness of BPKP Fraud Audit Finding on Determining the Level of Corruption in Indonesia Provinces (2012-2015). Jurnal Society and Governance.

Sitorus, C. P., \& Rahayu, S. (2018). Pengaruh Transparansi dan akuntabilitas Terhadap Tingkat Korupsi (Studi pada Pemerintah Daerah di Indonesia yang Disurvei oleh KPK di Tahun 2013). e-Proceeding of Management, 2395.

Suhardjanto, D., Syafruddin, M., Andini, R. P., \& Rahmatika, M. W. (2018). Accuntability and Corruption Level of Provincial Government in Indonesia. Review of Integrative Business \& Economics Research, vol 3, issue 3.

Verawaty, Puspita, I., \& Sularti, E. (2019). Pengaruh BPK, Karakteristik Pemerintah dan Indeks Pembangunan Manusia terhadap Tingkat Korupsi Pemerintah Daerah di Indonesia . MBIA, Vol.18, No.2.

ARTIKEL :

Azhar, K., \& Setyaningrum, D. (2015). Pengaruh Temuan dan Tindak Lanjut hasil Audit Pemeriksaan BPK Terhadap Korupsi Kementerian/Lembaga di Indonesia. [Online]. Tersedia:

http://lib.ui.ac.id/naskahringkas/201810/S59195-Khaliful\%20Azhar

Transparency International. (2019). Corruption Perception Index 2018. [Online]. Tersedia : https://www.transparency.org/ [30 Januari 2019]

Indonesia Corruption Watch. (2019). Laporan Tren Penindakan Kasus Korupsi 2018. [Online].
Universitas Telkom

https://antikorupsi.org/id/tren/tren-penindakankasus-korupsi-2018 [07 Februari 2019]

Indonesia Corruption Watch. (2019). Permintaan Data Kasus Korupsi Jawa Barat 2017-2018

Undang-undang, Peraturan Pemerintah dan lainlain :

Undang-Undang Republik Indonesia Nomor 15 Tahun 2006. Tentang Badan Pemeriksa Keuangan. Indonesia.

Undang-Undang Republik Indonesia Nomor 15 Tahun 2004. Tentang Pemeriksaan Pengelolaan dan Tanggung Jawab Keuangan Negara. Indonesia

Undang-Undang Republik Indonesia Nomor 20 Tahun 2001. Tentang Pemberantasan Tindak Pidana Korupsi. Indonesia.

Undang-Undang Republik Indonesia Nomor 23 Tahun 2014. Tentang Pemerintah Daerah. Indonesia.

Badan Pemeriksa Keuangan. (2019). Ikhtisar Hasil Pemeriksaan Semester I

Badan Pemeriksa Keuangan. (2019). Daftar Rekapitulasi Hasil Pemantauan TindakLanjut Hasil Rekomendasi Hasil Pemeriksaan Pada Pemerintah Daerah IHPS I

Badan Pusat Statistik. (2019). Populasi Provinsi Jawa

Barat 